\title{
Estimating the effects of global oil market shocks on Australian merchandise trade
}

\author{
M-Ali Sotoudeh ${ }^{\mathrm{a}, \mathrm{b}, *}$, Andrew C. Worthington ${ }^{\mathrm{a}}$ \\ ${ }^{a}$ Department of Accounting, Finance and Economics, Griffith University, Brisbane, Australia \\ ${ }^{b}$ Department of Economics, University of Sistan and Baluchestan, Zahedan, Iran
}

\begin{abstract}
In this paper, we examine the dynamic responses of Australian merchandise trade to global oil market structural shocks. The analysis employs monthly data over the period June 1986 to January 2013 and vector generalised autoregressive conditional heteroscedasticity (VGARCH), structural vector autoregression (SVAR), and parametric nonlinear models. We find that an increase in the oil price driven by shocks in global economic activity exerts a significant influence on Australian merchandise exports, and thereby merchandise trade as a whole, for periods of more than one year. However, the responses of merchandise imports to oil price shocks are more modest and persist for only a few months. Finally, uncertainty in future global oil prices, as measured by volatility in the 3-month-ahead price, strongly and negatively affects Australian international commodity markets.
\end{abstract}

JEL classification:

F14

O56

Q45

Keywords:

Oil price volatility Merchandise trade Structural shocks Vector generalised autoregressive conditional heteroscedasticity (VGARCH) Structural vector autoregression (SVAR)

Australia

* Corresponding author. Tel.: +61 730408639.

E-mail address: ma.sotoudeh@griffithuni.edu.au (M-A. Sotoudeh) 


\section{Introduction}

Since it was first refined in China around 2,000 BC, oil has increasingly dominated almost every aspect of the global economy. For instance, numerous studies conclude that increasing oil prices forecast most recessions in the modern era. For example, in seminal work, Hamilton (1983) observed that an oil price increase has preceded all post-WWII US recessions other than in the 1960s. Subsequently, many studies have confirmed Hamilton's (1983) finding, although some suggest that the 1973, 1979 and 1990 recessions in the US are more attributable to monetary policy than any oil price shocks (Burbidge and Harrison, 1984; Gisser and Goodwin, 1986; Bernanke et al., 1997).

Nevertheless, as a tradable commodity, most consider oil as a primary impetus for international trade, with oil price volatility accounting for major uncertainty in the future prices of nearly all goods and services. In turn, this encourages consumers to postpone their purchases of durable commodities and for firms to delay investment. Assume international trade to be a function of aggregate expenditure, the resultant weakening of current aggregate demand given the decline in domestic consumption and investment may reduce the volume of international trade.

As a macroeconomic sector forming economic output, international trade transfers the effects of global oil price shocks to GDP, with most extant research suggesting that oil price shocks have a significant influence on international trade. For instance, Backus and Crucini (2000) showed that oil price movements explain much of the changes in global trade during the period between 1972 and 1987. Employing a dynamic equilibrium model for eight developed countries, Backus and Crucini (2000) concluded that oil prices and not exchange rates more accurately explain the terms of trade. Using a structural vector autoregression (SVAR) model, Otto (2003) confirmed the positive relationship between oil price shocks and the terms of trade, and more importantly, demonstrated a similar relationship for both developed and developing countries.

Likewise, Baffes (2007) concluded that oil price shocks have strong effects on the prices of traded commodities. Using annual data for 35 primary commodities traded internationally during 1960-2005, Baffes (2007) argued that increases in oil prices reduce industrial production through declining disposable income. Finally, using an autoregressive distributed lags (ARDL) model, Hassan and Zaman (2012) concluded that oil price shocks reduce international trade for Pakistan. 
Current research suggests that the trade effects of oil price shocks vary depending on different economic circumstances. For example, building upon Backus and Crucini (2000), Bodenstein et al. (2011) found that under complete but not incomplete financial markets, oil price shocks have no effect on the nonoil terms of trade. Chen and Hsu (2012) employed a data set for 84 countries and compared the effects of oil price shocks between net oil importing and exporting countries, showing that oil price shocks have a negative impact on the international trade of the former and an insignificant positive effect on the international trade of the latter.

Lastly, Le and Chang (2013) also observed that the effects of oil price shocks on trade balance are country specific. Using Toda and Yamamoto's (1995) causality test and generalized impulse response functions, Le and Chang (2013) showed that in Japan, as an oilimporting country, the oil price impacted both oil and nonoil trade balances, whereas in Malaysia, as an oil-exporting country, the causation ran from oil price shocks to oil and overall trade balances. However, in Singapore, as an oil-refining country, there was no such causality detected. Bollino (2007), Kilian et al. (2009), and Korhonen and Ledyaeva (2010) obtained similar results concerning the effects of oil price shocks on trade balances.

Reviewing these studies reveals three major gaps in the literature. Firstly and foremost, no study addresses the effects of oil price shocks on the international trade of an economy with roughly equal oil production and consumption, such as in Australia. Second, there is little evidence addressing the responses of international trade to structural oil market shocks. Accordingly, it is currently unclear whether oil price shocks with separate origins affect the terms of trade identically. Finally, the number of studies employing relatively high-frequency data is somewhat limited, and this is likely to obscure some pertinent features of this sort of analysis.

These motivate us to consider the effects of global oil price shocks with different supply and demand origins on Australia's merchandise trade. To do so, we first estimate the global oil market structural shocks using the SVAR model proposed by Kilian (2009). We then consider possible dynamic nonlinear causation running from oil market shocks to Australia's merchandise trade. Finally, given the importance of uncertainty relating to future oil prices, we calculate oil price volatility using several alternative measurement methods and then analyse impulse response functions using vector autoregression (VAR).

The remainder of the paper is structured as follows. Section 2 discusses Australia's merchandise trade with its leading trading partners. Sections 3 and 4 present the data, 
methodology and empirical results, respectively. Finally, Section 5 summarises the main findings.

\section{Global oil prices and Australian merchandise trade}

Merchandise trade comprises goods that add or subtract from the stock of material resources of a country by entering (imports) or leaving (exports) its economic territory. Goods simply transported through a country (goods in transit), or temporarily admitted or withdrawn (except for goods for inward or outward processing), are not included. For this reason, a major early driver of merchandise trade was shipping and shipping costs. For example, technological progress in international shipping during 1850-1913 led to a significant reduction in the cost of international trade for many countries, including Australia (North, 1958, 1968; Harley, 1980, 1989; Saif and Williamson, 2004). Econometric evidence has subsequently linked recent declines in shipping costs to rapid growth in international trade during early globalisation (Estevadeordal et al., 2003). However, there is no evidence supporting this linkage during the recent years. Overall, countries with adjacent borders and the possibility of land transport account for roughly 23 per cent of global international merchandise trade by value (1-5 percent in Africa, the Middle East and Asia, 10-20 percent in Latin America, and 25-35 percent in Europe and North America) (Hummels, 2007). Obviously, for nonadjacent countries, all merchandise trade is by sea or air.

\section{$<$ TABLE 1 ABOUT HERE $>$}

Australia as a country with no adjacent land neighbours such that only the sea and air modes are available for its international trade. The necessity of trading with partners farther afield has raised Australia's cost of trade compared with many other countries. Consequently, we expect any shock in global oil prices to significantly impact upon its trade volume. Tables 1-2 provide some statistics concerning Australia's international trade with its top-10 partners. As shown in Table 1, more than a quarter of Australia's exports, contributing about 5.5 percent to Australian GDP, are with China and the US, even though both are a significant distance from Australia. Equally importantly, nearly 80 percent of Australia’s export trade volume with these top-10 partners is as merchandise trade. Of Australia's export markets, New Zealand is the closest, but only accounting for about half a percent of merchandise exports. 
As shown in Table 2, the composition of Australia's top-10 merchandise importing countries is similar to that for exports, except that India and Taiwan replace Germany and Thailand. Consequently, Australia's imports travel father than its exports. Table 2 also shows that with China accounting for 15 percent of Australia's total imports, and the US, UK, and Germany another 19.6 percent, the long distance from major trade partners and the large share of merchandise to total trade highlights the significant contribution of shipping costs to the costs of trade. Accordingly, oil price volatility should account for significant variation in the Australian trade balance.

In addition to the shipping cost, the volume of tradable oil substitutionary or complementary goods in total trade also determines merchandise trade vulnerability from oil price variation. Based on Australian Department of Foreign Affairs and Trade statistics, more than 17 per cent of total exports are coal and natural gas as complete substitutes for crude oil. The demand for these materials, which will affect Australia's trade balance, may also fluctuate because of oil price shocks. In contrast, crude petroleum, passenger cars and goods vehicles represent more than 13.7 percent of Australia's total imports. This indicates that an oil price shock may reduce the volume of imported goods due to their oil-complementary nature. Nevertheless, oil shocks driven by domestic economic activity or increasing oilspecific demand may generate different effects.

\section{$<$ TABLE 2 ABOUT HERE>}

To better visualise the comovement between the global oil price and Australia's international trade balance, we plot Figure 1, with both the oil price and the merchandise trade balance in real US dollars (per barrel and billions, respectively). We can readily identify three separate periods relevant to this relationship: the period before 1999, a period between 1999 and 2002, and the period after 2002. During the first period, we observe no significant relationship between oil prices and merchandise trade, with a correlation coefficient of just 0.55. During the second period, the trends in both series are closer, with a correlation coefficient of 0.66 . Finally, after 2002 the correlation coefficient of 0.80 demonstrates such significant comovement. Nonetheless, despite some variation over time, we generally observe that global oil price changes increasingly affect Australia’s international merchandise trade. 


\section{Data and methodology}

\subsection{Data}

For our analysis, we employ visible international export and import data for Australia, obtained from the OECD. We also use the OECD's nominal exchange rate and consumer price index data for the US and Australia to calculate the real values of trade, exports and imports in real US dollars and the daily West Texas Intermediate (WTI) spot price of oil from the Energy Information Administration (EIA). Finally, we collect global crude oil production data also from EIA as well as the index of real economic activity in the industrial commodity market presented on Lutz Kilian's (cite and reference) personal webpage. All data are monthly frequency and cover the period from June 1986 to January 2013.

\subsection{Oil price volatility}

The price of crude oil and petroleum products is easily influenced by events, which potentially disrupt the flow of oil and its products to oil-intensive industries and commodity markets. Such events make real oil prices unstable and volatile. Consequently, volatile oil prices create uncertainty in future oil supply or demand. Such uncertainty strengthens oil price volatility. The existing literature largely confirms this bilateral relationship between oil price volatility and uncertainty in future oil prices, as measured by real oil price volatility (e.g. Elder and Serletis, 2010).

Based on the literature, there are several methods available to calculate oil price volatility. These include standard deviation volatility (VSD), realized volatility (VR) and vector generalised autoregressive conditional heteroscedasticity (VGARCH) model volatility. To estimate each, we first calculate the daily oil price change:

$$
r_{t}=\log \left(\operatorname{pod}_{t}\right)-\log \left(\operatorname{pod}_{t-1}\right)
$$

where $r_{t}$ is the daily oil price change and $\operatorname{pod}_{t}$ is the WTI daily oil price index. We calculate in order each volatility index using the following formulas:

$$
V S D_{t}=\left(\frac{1}{D-1} \sum_{t=1}^{D}\left(r_{t}-\frac{1}{D} \sum_{t=1}^{D} r_{t}\right)^{2}\right)^{\frac{1}{2}}
$$




$$
\begin{aligned}
& V R_{t}=\sum_{t=1}^{D} r_{t}^{2} \\
& \operatorname{VGARCH}_{t}=\frac{1}{D} \sum_{t=1}^{D} \sigma_{t}^{2}
\end{aligned}
$$

where $D$ is the number of monthly trading days and $\sigma_{t}^{2}$ is the $\operatorname{GARCH}(1,1)$ term using squared residuals of $r_{t}$ on its mean. Finally, we measure the monthly oil price volatility by averaging the calculated GARCH terms.

\section{$<$ FIGURE 2 ABOUT HERE > \\ $<$ TABLE 3 ABOUT HERE >}

The pairwise correlation coefficients between the three volatility indices indicate that they are broadly similar, i.e. Corr(VSD, VRV) $=0.924$, Corr (VSD, VGARCH $)=0.932$ and Corr $(\mathrm{VRV}, \mathrm{VGARCH})=0.997$. To further consider the consistency of the measured volatilities, we plot Figure 2, which includes these and selected macro events. As Kilian (2009) argues, prior to 1992, structural supply shocks largely preceded major oil price shocks; afterwards, global demand shocks were the main drivers.

The coincidence of global oil price volatility with major events driving oil price shocks plotted in Figure 2 accords with work by Kilian (2009), Hamilton (2009a, 2009b) and Filis et al. (2011). For example, the oil-specific demand shock of 1990-91 corresponded to the invasion of Kuwait by Iraq, the First Gulf War, and the Collapse of the Soviet Union. Likewise, Chinese economic growth and the Global Financial Crisis drove oil price shocks during the period 2006-09 through aggregate demand mechanisms.

\subsection{Structural shocks and model specification}

In this paper, we estimate crude oil market shocks using the two-block structural shock proposed by Kilian (2009). The standard SVAR model is as follows:

$$
\boldsymbol{A} \boldsymbol{Y}_{\boldsymbol{t}}=\alpha+\sum_{i=1}^{24} \boldsymbol{B}_{\boldsymbol{i}} \boldsymbol{Y}_{\boldsymbol{t}-\boldsymbol{i}}+\varepsilon_{t}
$$


where $\boldsymbol{Y}=(\triangle O S, \triangle R A, \Delta O P)^{\prime}$ is the log-difference of global oil supply, the Kilian index of global real economic activity, and the log-difference of the global real oil price, respectively. We assume the exogenous error terms $\left(\varepsilon_{t}\right)$ are serial and mutual structural innovations. $\boldsymbol{A}$ is a full-rank matrix such that $\boldsymbol{A}^{-\mathbf{1}}$ is a recursive structure defining the reduced form $e_{t}=\boldsymbol{A}^{\mathbf{- 1}} \varepsilon_{t}$. The decomposition is as follows:

$$
\begin{gathered}
e \equiv\left(\begin{array}{c}
e_{t}^{\Delta O S} \\
e_{t}^{\Delta R A} \\
e_{t}^{\Delta O P}
\end{array}\right)= \\
{\left[\begin{array}{ccc}
a_{11} & 0 & 0 \\
a_{21} & a_{22} & 0 \\
a_{31} & a_{32} & a_{33}
\end{array}\right]\left(\begin{array}{c}
\varepsilon_{t}^{\text {Oil supply shock }} \\
\varepsilon_{t}^{\text {Aggregate demand shock }} \\
\varepsilon_{t}^{\text {Other oil-specific shock }}
\end{array}\right)}
\end{gathered}
$$

Consequently, the structural innovations present oil market shocks as follows. To start, crude oil supply shocks are unanticipated innovations in global crude oil production. Shocks to the global demand for industrial commodities (aggregate demand shocks) are then those innovations to global real economic activity unexplained by crude oil supply shocks. Oilspecific demand shocks, which we interpret as precautionary demand shocks, are then innovations to the real price of oil unexplained by either oil supply or aggregate demand shocks.

There are some restrictive assumptions underlying the above decomposition. First, oil supply innovations do not respond to shocks in aggregate demand and other oil-specific shocks in the short-term. This allows us to consider oil supply shocks as exogenous. In practice, only oil producers have control over oil production and there is an at least onemonth delay in aggregate demand or other oil-specific shocks influencing the supply of oil. Second, global economic activity responds to global oil price shocks immediately, while oilspecific shocks have no effect on global economic activity in the short-term. Kilian (2009) explains how oil-specific shocks may influence global economic activity after a month.

Finally, as Kilian (2009) and Kilian and Park (2009) demonstrate, other oil-specific shocks are interpreted as precautionary demand shocks, which are induced by the expected shortfalls in oil supply. These shocks do not respond to exchange rate innovations in a country within a month mainly because they result from uncertainty in the future global oil supply. 
To investigate the linear responses of Australia's merchandise trade to the estimated shocks in crude oil market from Equations 5 and 6, we follow the linear approach presented by Kilian (2009) to measure the impulse responses. Consider the following equation:

$$
\begin{gathered}
M_{h t}=\delta_{h j}+\sum_{i=0}^{24} \varphi_{h j i} \hat{S}_{h j t-i}+\omega_{h j t} \\
=1,2,3
\end{gathered}
$$

where $M$ and $\hat{S}$ are the log-differences of the merchandise trade variables and estimated shocks using Equations 5 and 6, respectively. Because we include three variables for merchandise trade and three structural oil market shocks, $h$ and $j$ take values from $1-3$. Furthermore, $\delta$ is the constant term and $\omega$ is the error term. The purpose of estimating Equation 7 is to obtain the model coefficients $(\varphi)$, which report the trade responses to the impulses of each shock over a 24-month horizon. Consequently, we determine the number of lags by the maximum horizon of the impulse-response function. One problem in estimating Equation 7 is potential serial correlation in the error terms, yielding biased estimation of the standard errors. To avoid this, we employ bootstrap simulations to obtain the standard errors. Finally, we decompose the country-specific forecast error variance of each estimated shock to determine the contribution of these shocks to variations in the merchandise trade variables.

\subsection{Parametric nonlinear model}

Mackey and Glass (1977) have first applied the parametric nonlinear model employed in this paper using a bivariate noisy procedure in describing a physiological control system using chaos theory. Since then, their model has found application in several disciplines, and the modifications we employ here follow Kyrtsou and Labys (2006). The test is similar to the linear Granger causality test. However, it contains the Mackey-Glass model process with special parameters, which are estimated using ordinary least squares methods. Given the estimated oil price shocks $(\hat{S})$ and merchandise trade variables $(M)$, we conduct the test through the following formulations:

$$
\begin{gathered}
M_{i t}=\alpha_{j 11}\left(\hat{S}_{j t-\tau_{1}}\right)\left(1+\hat{S}_{j t-\tau_{1}}^{\mathrm{c}_{1}}\right)^{-1}-\delta_{j 11} \hat{S}_{j t-1}+\alpha_{i 12}\left(M_{i t-\tau_{2}}\right)\left(1+M_{i t-\tau_{2}}^{\mathrm{c}_{2}}\right)^{-1}-\delta_{i 12} M_{i t-1} \\
+u_{t}
\end{gathered}
$$


In this equation, we obtain the oil market shocks using the SVAR model in Section 3.3. The merchandise trade variables are in log-differences, $\tau=\max \left(\tau_{1}, \tau_{2}\right)$ is the calculated integer delay, $\mathrm{c}$ is the constant and $t=\tau, \tau+1, \ldots, N$. As we have three merchandise trade variables and three structural oil market shocks, $i$ and $j$ again take values equal to $1-3$. The parameters $\alpha$ and $\delta$ are the linear and nonlinear effects of the causal variables over the dependent variables, respectively. Finally, the two error terms $u_{t}$ and $\varepsilon_{t}$ are assumed $N(0,1)$.

We select the integer delays $\tau_{i}$ and constants $c_{i}$ prior to estimation of the model using the Schwarz criterion and the likelihood ratio. If the oil market shocks nonlinearly Granger-cause merchandise trade, $\alpha_{11}$ should be significantly different from zero (the null hypothesis). Thus, we need to estimate Equation 9 first with no constraint and then with the constraint of a zero value of $\alpha_{11}$. Assuming $\hat{\vartheta}$ and $\hat{\mu}$ are the residuals of the unconstrained and constrained nonlinear models, respectively, we then calculate a Fisher-distributed statistic as below:

$$
S_{F}=\frac{\left(S_{c}-S_{u}\right) / n_{c}}{S_{u} /\left(T-n_{u}-1\right)} \sim F\left(n_{c}, T-n_{u}-1\right)
$$

where $S_{u}=\sum_{t=1}^{T} \hat{\vartheta}^{2}, S_{c}=\sum_{t=1}^{T} \hat{\mu}^{2}, n_{u}=4$ because of estimating the four parameters in the Mackey-Glass model and $n_{c}=1$ as only one parameters needs to be zero when we estimate the constrained model. We also use a parametric nonlinear causality test to detect asymmetry in the nonlinear causal relationships. However, we may conduct an asymmetric version of the test if we detect any nonlinear causation between the target variables.

\section{Empirical results}

\subsection{Nonlinear causality}

To consider the dynamic effects of oil market shocks on Australia's merchandise trade, we first test whether there is any nonlinear causation running from global oil price shocks to the trade variables. Table 4 provides the results of the modified nonlinear causality test. The test delivers F-distributed statistics showing the significance of the nonlinear causation of the oil supply, aggregate demand and other oil-specific shocks over merchandise exports, imports, and total trade volume. Note the model is dynamic and employs predetermined temporal lags and power parameters (not shown in Table 4). As shown, none of the reported test statistics are statistically significant, indicating that the null hypothesis of the non-causation of the cause variables is not rejected. Hence, oil market shocks do not nonlinearly affect the 
Australian international commodity market. This finding justifies our main linear dynamic approach and strengthens our hypothesis of the linear causation of structural oil price shocks over merchandise trade variables.

\section{$<$ TABLE 4 ABOUT HERE $>$}

\subsection{Responses of merchandise trade variables to global oil market shocks}

In this section, we investigate the responses of merchandise exports, imports and trade to shocks in the global crude oil market, as estimated by Equations 6 and 7. Figure 3 illustrates the estimated results. As depicted, shocks in the crude oil market positively influence the merchandise trade variables. The coefficients are also statistically significant.

We summarise the findings of our structural model as follows. First, the effects of an unanticipated increase in global oil supply on merchandise exports (decreasing the oil price) are evident after 3 months and remain strongly positive for 18 months. However, the figure also shows that such responses may remain positive, even after more than 24 months. Merchandise imports, on the other hand, respond weaker than exports to global oil supply shocks, taking less than 3 months for the responses to appear, which then remain positive for just a few months.

As clearly shown in Figure 3, the positive effects of the oil supply shocks on exports and imports induce a positive response in total merchandise trade. The positive responses of total merchandise trade to global oil supply shock, which appear after 3 months, continue for a year, and so are weaker than the export response and stronger than the import response. We believe we can attribute these to the reduction in shipping costs. Additionally, the stronger effect of such shocks on merchandise exports than imports shed lights on the relative importance of Australia's exports. However, as discussed, this increase in merchandise trade does not continue over the longer term.

\section{$<$ FIGURE 3 ABOUT HERE $>$}

Second, unanticipated increases in global aggregate demand influence merchandise exports substantially positively after 6 months, with the effects persisting for more than 24 months. This suggests that Australia's merchandise exports are highly sensitive to fluctuations in global economic activity in the long-term. It also indicates that despite of significant positive effects of a shock in global economic activity on oil prices proposed by Kilian (2009), Australia’s merchandise exports are substantially increasing, and hence, there 
remains sufficient capacity to invest in exporting industries. Conversely, merchandise imports do not exhibit strong responses to global aggregate demand shocks. In evidence, the shortterm effects of the global aggregate demand shocks on merchandise imports are evident after 6 months and continue for another 4 months. We attribute this to the progressive demand for Australia’s capital and intermediate goods. Furthermore, the responses of total merchandise trade are substantially positive for 24 months. This modifies the stable position of Australia's international commodity market responding to shocks in global economic activity.

Finally, as Kilian (2009) discusses, oil-specific demand shocks present precautionary demand shocks driven by expectations about future shortfalls in the global oil supply. These shocks are supposed to exert a strong influence on the real price of oil. Figure 3 illustrates that such shocks exert significant pressure on merchandise exports, with the long-term substantially positive responses evident after 3 months persisting for long periods. Typical exporting commodities could justify the positive response of merchandise exports to oilspecific demand shocks. For example, metallurgical (coking) coal and liquid natural gas (LNG), as primary exporting commodities, are strong market substitutes for crude oil.

Given that oil-substituting commodities require a long time for changes in their utilisation, the estimated long-term horizon for merchandise exports is consistent with this assumption. This could be one reason why an unanticipated increase in crude oil price driven by precautionary demand shocks raises global demand for Australia's exports in the long term. In addition, Figure 5 shows that merchandise imports respond positively to oil-specific demand shocks. Such responses, found to proceed for a year, have a 3-month delay. Uncertainty regarding the shortfalls in future oil supply may explain such a temporary positive response to oil-specific demand shocks. Overall, total merchandise trade volume increases after 3 months and persists for more than 24 months.

\subsection{Contribution of oil price shocks to variations in merchandise trade variables}

To quantify the contribution of oil price shocks to variations in the merchandise trade variables, we employ variance decomposition analysis. Figure 4 depicts the variance decomposition results at forecast horizons of 1, 6, 12 and 24 months. As shown, the contribution of oil supply shocks to variations in merchandise exports and total trade volume is much greater than for the other oil market shocks, particularly in the short term (1 month). Oil supply shocks also explain more than 99 per cent of variations in merchandise exports in the short term. However, the explanatory power significantly decreases in the long term and 
is only 30 percent by 24 months. It is clear the estimated contribution of oil supply shocks to variations in total merchandise trade arises from the strong response of merchandise exports. However, the contribution of oil supply shocks to variations in merchandise imports is much less and varies over time.

\section{$<$ FIGURE 4 ABOUT HERE $>$}

In contrast, whereas aggregate demand shocks explain more than 51 percent of the variation in merchandise imports, they contribute almost nothing to explaining merchandise exports in the short term. Thus, the 7.5 per cent contribution of such shocks to variations in total trade in the short term is attributable to responses in merchandise imports. However, the power of aggregate demand shocks in explaining the variations in merchandise exports and merchandise trade increases in the long term.

Finally, whereas oil-specific demand shocks explain the least variation in merchandise trade, their contribution to the variation in merchandise imports is greater than that of the other shocks, at least in the long term. It is also worth noting that oil-specific demand shocks explain less than 1 percent of all variations in merchandise trade in the short term. Besides the increasing contribution of these shocks in the long term, merchandise imports suffer from such effects more severely than the other trade variables.

\subsection{Responses of merchandise trade variables to global oil price volatility}

Investigating the effects of uncertainty in future oil prices on the macroeconomy is of great interest. For instance, Pindyck (1991) suggests that oil price uncertainty explains the recessions of 1980 and 1982, Ferderer (1996) observes the adverse effects of oil price uncertainty on US output during the period 1970-90, and Hooker (1996) proves that such effects were stronger after 1973. For the most part, oil price uncertainty appears higher since the mid-1980s (Elder and Serletis, 2010).

We use oil price volatility as an index measure of uncertainty in the future oil price. To consider the dynamic responses of Australia's merchandise trade to real oil price volatility, we employ VAR impulse-response functions. Figure 5 illustrates the responses of Australia's merchandise trade, exports, and imports to oil price volatility, as described in Section 3.2. As shown, because of the high correlation between the measured indices of oil price volatility, the responses exhibit very similar movements. This is most evident in the responses to the $\mathrm{RV}$ and GARCH indices. The estimated direction of the responses to the oil price volatility 
satisfies our expectations, such that an unanticipated shock in oil price volatility affects merchandise exports and imports negatively. In both cases, these take 3-4 months to appear. This indicates that market activists respond negatively to permanent instability in oil price instability. Thus, temporary oil price fluctuations, which may take less than 3 months on average, do not materially affect merchandise exports and imports. These findings are consistent with those in Chen and Hsu (2012).

\section{$<$ FIGURE 5 ABOUT HERE $>$}

Finally, Figure 5 illustrates that the magnitude of the responses of merchandise imports to oil price volatility is greater than that for merchandise exports. Where the reduction in merchandise imports and exports are not equivalent, the realised and GARCH volatility indices imply the greater response of merchandise imports to shocks in oil price volatility. Consequently, we expect a decrease in total merchandise trade with unanticipated innovation in oil price volatility. As depicted in Figure 5, we somewhat modify this conclusion given the negative responses of merchandise trade to shocks in oil price volatility, such that an unanticipated shock in oil price volatility exerts a substantial negative influence on aggregate merchandise trade after 4 months. Once again, the delay implies that Australia's international commodity markets respond only to permanent variations in oil price shocks.

\section{Conclusion}

As a country surrounded by sea with no adjacent country sharing a land border, Australia trade internationally through sea and air. Further, over time, the large volume of oil-substitute exports as well as highly oil-intensive imports has raised the expected elasticity of Australia's international trade to shocks in the global oil market. In this paper, we studied the responses of Australia's international markets to structural global oil market shocks and global oil price volatility. Our findings indicate that shocks in global oil market exert a significant effect on merchandise trade. We summarise the findings of the paper and their implications as follows.

First, global oil supply shocks, which induce global oil price disruptions, affect merchandise trade with a 3-month delay. We found that the responses of merchandise exports to global oil supply shocks are much more sensitive than for merchandise imports. We attribute the positive effects of oil supply shocks on merchandise trade to a reduction in the cost of shipping. Regardless, the effects of oil supply shocks last no longer than 18 months, 
and while they explain more than 99 percent of the variations in merchandise trade in the short term, it is much less in the longer term.

Second, global aggregate demand shocks exert a substantial long-term positive effect on merchandise exports and the trade balance, whereas such effects have only a minor and temporary effect on merchandise imports. These responses seem weaker than the responses to oil supply shocks, even though they are more persistent. They also only appear after about 6 months. The substantial positive effects of aggregate demand shocks on merchandise exports modify the important position of Australia's merchandise exports in global economic activity. This finding indicates that further investment in exporting industries may provide substantial benefits, with the modest short-term rise in merchandise imports implying growth in Australian economic activity alongside other countries. In addition, while aggregate demand shocks explain half of the variation in merchandise imports in the short term, they do not contribute to the variation in merchandise exports. However, the contribution of aggregate demand shocks to variations in merchandise exports increases over time.

Third, expectations about future oil supply shortfalls, which induce oil-specific (precautionary) demand shocks, impact merchandise exports and the trade balance substantially positively in the long term. However, merchandise imports respond positively for less than a year. The effects of oil-specific shocks take at least 3 months on average to manifest themselves. The long-term effects of oil-specific demand shocks on Australia's merchandise trade could then be attributable to the high volume of oil-substitute exports such as coking coal and LNG. This finding again shows that further investment in exporting manufactures and producing oil-substitute commodities may benefit Australia's international market position. Additionally, oil-specific demand shocks explain the major variations in merchandise imports in the long term.

Finally, our findings indicate that Australia's international markets respond strongly negatively to uncertainty to global oil prices. Any shock in real oil price volatility, which reflects uncertainty in the global oil market, influences merchandise trade, exports and imports after 3-4 months. Thus, we consider an unexpected shock in the real oil price as temporary when it persists for less than 3 months. This finding suggests market activists should only consider those market fluctuations resulting from 3-month-ahead oil price volatilities.

We suggest it would be interesting in the future to reconsider the relationship between domestic oil prices and the real exchange rate. In addition, firm-level investigations, which cover domestic oil-intensive and nonoil-intensive exporting industries, may provide detailed 
guidelines for investors developing exporting industries. Finally, testing for asymmetry in the responses of the international commodity market to oil price shocks would deliver complementary information to understand international market demand more thoroughly.

\section{References}

Backus, D.K. and M.J. Crucini (2000). Oil prices and the terms of trade, Journal of international economics. 50: 185-213. http://dx.doi.org/10.1016/s0022-1996(98)00064-6

Baffes, J. (2007). Oil spills on other commodities, Resources Policy. 32: 126-134. http://dx.doi.org/10.1016/j.resourpol.2007.08.004

Bernanke, B.S., Gertler, M., Watson, M., Sims, C.A., and B.M. Friedman (1997). Systematic monetary policy and the effects of oil price shocks, Brookings Papers on Economic Activity. 1: 91-157. http://dx.doi.org/10.2307/2534702

Bodenstein, M., Erceg, C.J., and L. Guerrieri (2011). Oil shocks and external adjustment, Journal of international economics. 83: 168-184. http://dx.doi.org/10.2139/ssrn.1003167

Bollino, C.A. (2007). Oil prices and the US trade deficit, Journal of Policy Modeling. 29: 729-738. http://dx.doi.org/10.1016/j.jpolmod.2007.06.009

Burbidge, J. and A. Harrison (1984). Testing for the effects of oil-price rises using vector autoregressions, International Economic Review. 25: 459-484. http://dx.doi.org/10.2307/2526209

Chen, S.S. and K.W. Hsu (2012). Reverse globalization: Does high oil price volatility discourage international trade?, Energy Economics. 34: 1634-1643. http://dx.doi.org/10.1016/j.eneco.2012.01.005

Elder, J. and A. Serletis (2010). Oil price uncertainty, Journal of Money, Credit and Banking. 42: 1137-1159. http://dx.doi.org/10.1111/j.1538-4616.2010.00323.x

Estevadeordal, A., Frantz, B., and A.M. Taylor (2003). The rise and fall of world trade, 1870 - 1939, The Quarterly Journal of Economics. 118: 359-407. http://dx.doi.org/10.1162/003355303321675419

Ferderer, P.J. (1996). Oil price volatility and the macroeconomy, Journal of Macroeconomics. 18: 126. http://dx.doi.org/10.1016/s0164-0704(96)80001-2

Filis, G., Degiannakis, S., and C. Floros (2011). Dynamic correlation between stock market and oil prices: The case of oil-importing and oil-exporting countries, International Review of Financial Analysis. 20: 152-164. http://dx.doi.org/10.1016/j.irfa.2011.02.014

Gisser, M. and T.H. Goodwin (1986). Crude oil and the macroeconomy: Tests of some popular notions: Note, Journal of Money, Credit and Banking. 18: 95-103. http://dx.doi.org/10.2307/1992323

Hamilton, J.D. (1983). Oil and the macroeconomy since world war II, Journal of Political Economy. 91: 228-248. http://dx.doi.org/10.1086/261140

Hamilton, J.D. (2009a). Understanding crude oil prices, The Energy Journal. 30: 179-203. http://dx.doi.org/10.5547/issn0195-6574-ej-vol30-no2-9

Hamilton, J.D. (2009b). Causes and consequences of the oil shock of 2007-08', National Bureau of Economic Research Working Paper Series, No. 09-02. University of California, San Diego. http://dx.doi.org/10.2139/ssrn.2583456

Harley, C.K. (1980). Transportation, the world wheat trade, and the Kuznets Cycle, 1850-1913, Explorations in Economic History. 17: 218-250. http://dx.doi.org/10.1016/0014-4983(80)90011$\mathrm{x}$

Harley, C.K. (1989). Coal exports and British shipping, 1850 - 1913, Explorations in Economic History. 26: 311-338. http://dx.doi.org/10.1016/0014-4983(89)90024-7

Hassan, S.A. and K. Zaman (2012). Effect of oil prices on trade balance: New insights into the cointegration relationship from Pakistan, Economic Modelling. 29: 2125-2143. http://dx.doi.org/10.1016/j.econmod.2012.07.006 
Hooker, M.A. (1996). What happened to the oil price-macroeconomy relationship?, Journal of Monetary Economics. 38: 195-213. http://dx.doi.org/10.1016/s0304-3932(96)01281-0

Hummels, D. (2007). Transportation Costs and International Trade in the Second Era of Globalization, Journal of Economic Perspectives. 21: 131-154. http://dx.doi.org/10.1257/jep.21.3.131

Kilian, L. (2009). Not all oil price shocks are alike: disentangling demand and supply shocks in the crude oil market, The American Economic Review. 99: 1053-1069. http://dx.doi.org/10.1257/aer.99.3.1053

Kilian, L. and C. Park (2009). The impact of oil price shocks on the U.S. stock market, International Economic Review. 50: 1267-1287. http://dx.doi.org/10.1111/j.1468-2354.2009.00568.x

Kilian, L., Rebucci, A., and N. Spatafora (2009). Oil shocks and external balances, Journal of international economics. 77: 181-194. http://dx.doi.org/10.1016/j.jinteco.2009.01.001

Korhonen, I. and S. Ledyaeva (2010). Trade linkages and macroeconomic effects of the price of oil, Energy Economics. 32: 848-856. http://dx.doi.org/10.1016/j.eneco.2009.11.005

Kyrtsou, C. and W.C. Labys (2006). Evidence for chaotic dependence between US inflation and commodity prices, Journal of Macroeconomics. 28: 256-266. http://dx.doi.org/10.1016/j.jmacro.2005.10.019

Le, T.H., and Y. Chang (2013). Oil price shocks and trade imbalances, Energy Economics 36: 78-96. http://dx.doi.org/10.1016/j.eneco.2012.12.002

Mackey, M.C. and L. Glass (1977). Oscillation and chaos in physiological control systems, Science (New York, N.Y.). 197: 287-289. http://dx.doi.org/10.1126/science.267326

North, D. (1958). Ocean Freight Rates and Economic Development 1750-1913, The Journal of Economic History. 18: 537-555. http://www.jstor.org/stable/2114547

North, D.C. (1968). Sources of Productivity Change in Ocean Shipping, 1600-1850, The Journal of Political Economy. 76: 953-970. http://dx.doi.org/10.1086/259462

Otto, G. (2003). Can an Intertemporal Model Explain Australia's Current Account Deficit?, The Australian Economic Review. 36: 350-359. http://dx.doi.org/10.1111/1467-8462.00294

Pindyck, R.S. (1991). Irreversibility, uncertainty, and investment, Journal of Economic Literature. 29: 1110-1148. http://www.jstor.org/stable/2727613

Saif, I.S.M., and J.G. Williamson (2004). Freight rates and productivity gains in British tramp shipping 1869-1950, Explorations in Economic History. 41: 172-196. http://dx.doi.org/10.1016/s0014-4983(03)00043-3

Toda, H.Y. and T. Yamamoto (1995). Statistical inference in vector autoregressions with possibly integrated processes, Journal of Econometrics. 66: 225-250. http://dx.doi.org/10.1016/03044076(94)01616-8 


\section{Table 1}

Australia’s top-10 export markets, 2013

\begin{tabular}{|c|c|c|c|c|c|c|}
\hline Country & Rank & Goods & Services & Total & Share & Distance $(\mathrm{km})$ \\
\hline China & 1 & $\begin{array}{c}94,655 \\
(6.03)\end{array}$ & $\begin{array}{l}6,881 \\
(0.44)\end{array}$ & $\begin{array}{c}101,536 \\
(6.47)\end{array}$ & 31.9 & $7,482.73$ \\
\hline Japan & 2 & $\begin{array}{c}47,501 \\
(3.03)\end{array}$ & $\begin{array}{l}1,991 \\
(0.13)\end{array}$ & $\begin{array}{c}49,492 \\
(3.15)\end{array}$ & 15.5 & $6,859.99$ \\
\hline Republic of Korea & 3 & $\begin{array}{l}1,961 \\
(1.25)\end{array}$ & $\begin{array}{l}1,675 \\
(0.11)\end{array}$ & $\begin{array}{c}21,285 \\
(1.36)\end{array}$ & 6.7 & $6,840.02$ \\
\hline United States & 4 & $\begin{array}{c}958 \\
(0.61)\end{array}$ & $\begin{array}{l}5,951 \\
(0.38)\end{array}$ & $\begin{array}{c}15,531 \\
(0.99)\end{array}$ & 4.9 & $15,201.49^{\mathrm{a}}$ \\
\hline India & 5 & $\begin{array}{l}9,517 \\
(0.61)\end{array}$ & $\begin{array}{l}1,921 \\
(0.12)\end{array}$ & $\begin{array}{c}11,438 \\
(0.73)\end{array}$ & 3.6 & 7,822.21 \\
\hline New Zealand & 6 & $\begin{array}{l}7,399 \\
(0.47)\end{array}$ & $\begin{array}{l}3,626 \\
(0.23)\end{array}$ & $\begin{array}{c}11,025 \\
(0.70)\end{array}$ & 3.5 & $4,162.27$ \\
\hline Singapore & 7 & $\begin{array}{l}5,659 \\
(0.36)\end{array}$ & $\begin{array}{l}3,549 \\
(0.23)\end{array}$ & $\begin{array}{l}9,208 \\
(0.59)\end{array}$ & 2.9 & $4,381.46$ \\
\hline Taiwan & 8 & $\begin{array}{l}7,356 \\
(0.47)\end{array}$ & $\begin{array}{c}704 \\
(0.04)\end{array}$ & $\begin{array}{l}8,060 \\
(0.51)\end{array}$ & 2.5 & $5,623.92$ \\
\hline United Kingdom & 9 & $\begin{array}{l}3,859 \\
(0.24)\end{array}$ & $\begin{array}{l}3,982 \\
(0.25)\end{array}$ & $\begin{array}{l}7,841 \\
(0.50)\end{array}$ & 2.5 & $15,223.07$ \\
\hline Malaysia & 10 & $\begin{array}{l}5,561 \\
(0.35)\end{array}$ & $\begin{array}{l}1,664 \\
(0.11)\end{array}$ & $\begin{array}{l}7,225 \\
(0.46)\end{array}$ & 2.3 & $4,751.42$ \\
\hline Total exports & & $\begin{array}{l}263467 \\
(16.79)\end{array}$ & $\begin{array}{l}55175 \\
(3.51)\end{array}$ & $\begin{array}{l}318642 \\
(20.30)\end{array}$ & 100.0 & \\
\hline
\end{tabular}

Notes: Goods, Services, and Total in millions of \$A. Export shares of GDP in parentheses. (a) denotes the closest distance via the Pacific Ocean.

Source:

Department of Foreign Affairs and Trade.

Australian Bureau of Statistics.

Distancefromto website. 
Table 2

Australia’s top-10 import sources, 2013

\begin{tabular}{|c|c|c|c|c|c|c|}
\hline Country & Rank & Goods & Services & Total & Share & Distance $(\mathrm{km})$ \\
\hline China & 1 & $\begin{array}{c}47,250 \\
(3.01)\end{array}$ & $\begin{array}{l}2,079 \\
(0.13)\end{array}$ & $\begin{array}{c}49,329 \\
(3.14)\end{array}$ & 15.0 & $7,482.73$ \\
\hline United States & 2 & $\begin{array}{c}26,681 \\
(1.70)\end{array}$ & $\begin{array}{c}12,430 \\
(0.79)\end{array}$ & $\begin{array}{l}39,181 \\
(2.49)\end{array}$ & 11.9 & $15,201.49^{\mathrm{a}}$ \\
\hline Japan & 3 & $\begin{array}{l}18,914 \\
(1.20)\end{array}$ & $\begin{array}{l}2,307 \\
(0.15)\end{array}$ & $\begin{array}{l}21,221 \\
(1.35)\end{array}$ & 6.5 & 6,859.99 \\
\hline Singapore & 4 & $\begin{array}{c}12,933 \\
(0.82)\end{array}$ & $\begin{array}{l}4,943 \\
(0.31)\end{array}$ & $\begin{array}{l}17,878 \\
(1.14)\end{array}$ & 5.4 & $4,381.46$ \\
\hline Thailand & 5 & $\begin{array}{c}11,393 \\
(0.72)\end{array}$ & $\begin{array}{l}2,439 \\
(0.15)\end{array}$ & $\begin{array}{c}13,832 \\
(0.88)\end{array}$ & 4.2 & $5,797.85$ \\
\hline Germany & 6 & $\begin{array}{c}11,428 \\
(0.73)\end{array}$ & $\begin{array}{l}1,665 \\
(0.11)\end{array}$ & $\begin{array}{c}13,099 \\
(0.83)\end{array}$ & 4.0 & $14,482.43$ \\
\hline United Kingdom & 7 & $\begin{array}{l}6,195 \\
(0.39)\end{array}$ & $\begin{array}{l}5,848 \\
(0.37)\end{array}$ & $\begin{array}{l}12,044 \\
(0.77)\end{array}$ & 3.7 & $15,223.07$ \\
\hline Malaysia & 8 & $\begin{array}{l}9,480 \\
(0.60)\end{array}$ & $\begin{array}{l}1,464 \\
(0.09)\end{array}$ & $\begin{array}{c}10,944 \\
(0.70)\end{array}$ & 3.3 & $4,751.42$ \\
\hline Republic of Korea & 9 & $\begin{array}{c}10,168 \\
(0.65)\end{array}$ & $\begin{array}{c}646 \\
(0.04)\end{array}$ & $\begin{array}{l}10,813 \\
(0.69)\end{array}$ & 3.3 & $6,840.02$ \\
\hline New Zealand & 10 & $\begin{array}{l}7,401 \\
(0.47)\end{array}$ & $\begin{array}{l}3,131 \\
(0.20)\end{array}$ & $\begin{array}{c}10,532 \\
(0.67)\end{array}$ & 3.2 & $4,162.27$ \\
\hline Total imports & & $\begin{array}{c}25,8936 \\
(16.50)\end{array}$ & $\begin{array}{l}69,870 \\
(4.45)\end{array}$ & $\begin{array}{c}328,806 \\
(20.95)\end{array}$ & 100.0 & \\
\hline
\end{tabular}

Notes: Goods, Services, and Total in millions of \$A. Import shares of GDP in parentheses. (a) denotes the closest distance via the Pacific Ocean.

Source:

Australian Department of Foreign Affairs and Trade.

Australian Bureau of Statistics.

Distancefromto website.

Table 3

Main events and corresponding oil price volatilities

\begin{tabular}{clc}
\hline Identification & \multicolumn{1}{c}{ Event } & Year \\
\hline E.1 & Non-OPEC oil production acceleration & 1986 \\
E.2 & Iraq Invasion in Kuwait & 1990 \\
E.3 & First Gulf War & 1991 \\
E.4 & OPEC oil production cuts & 1998 \\
E.5 & OPEC oil production cuts & 1999 \\
E.6 & September Terrorist Attack in the US & 2001 \\
E.7 & PDVSA workers' strike & 2002 \\
E.8 & Second Gulf War & 2003 \\
E.9 & Global Financial Crisis & 2008 \\
\hline
\end{tabular}


Table 4

Parametric nonlinear $\mathrm{M}-\mathrm{G}$ model test

\begin{tabular}{lccc}
\hline \multirow{2}{*}{ Cause variable } & \multicolumn{3}{c}{ Effect variable } \\
\cline { 2 - 4 } & Export & Import & Trade \\
\hline Oil supply shock & 0.6858 & 1.3158 & 0.0718 \\
Aggregate demand shock & 0.2467 & 0.0238 & 0.3427 \\
Other oil-specific shocks & 0.3387 & 0.1758 & 0.3017 \\
\hline
\end{tabular}

Notes: Test statistics F-distributed. The null hypothesis is that there is no nonlinear causal relationship running from oil market shocks to merchandise trade.

\section{Figure 1}

Australian visible international trade volume and global oil price (19862012)

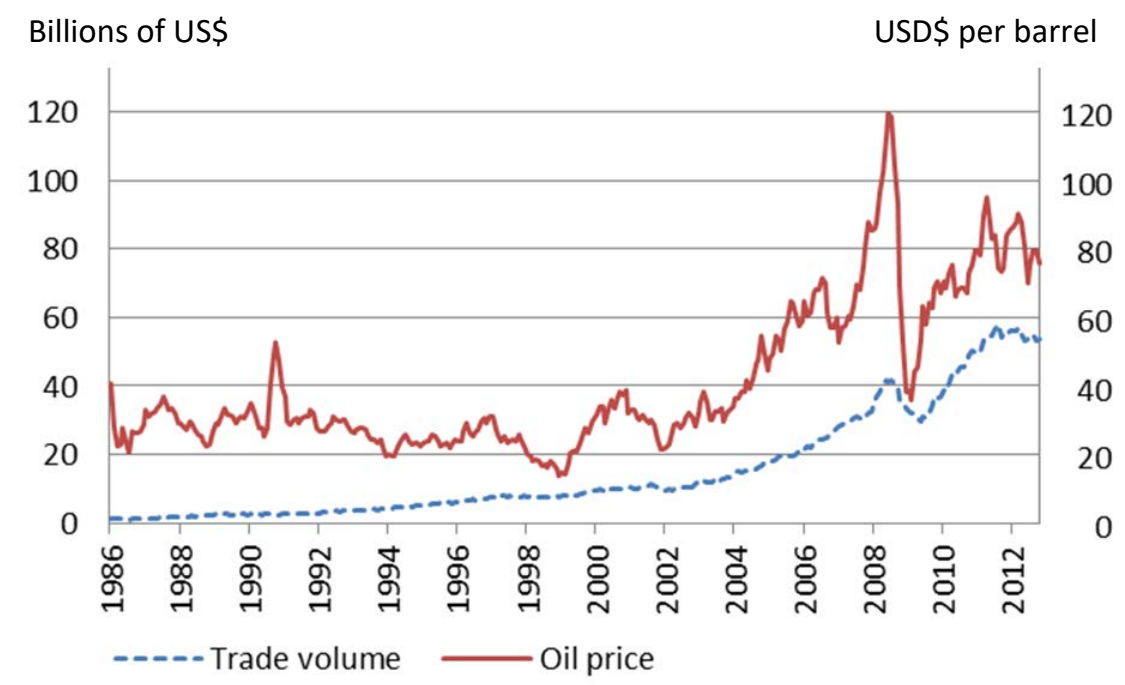

Source: OECD

\section{Figure 2}

Oil price volatility (GARCH) and major events: 1986M1-2013M5

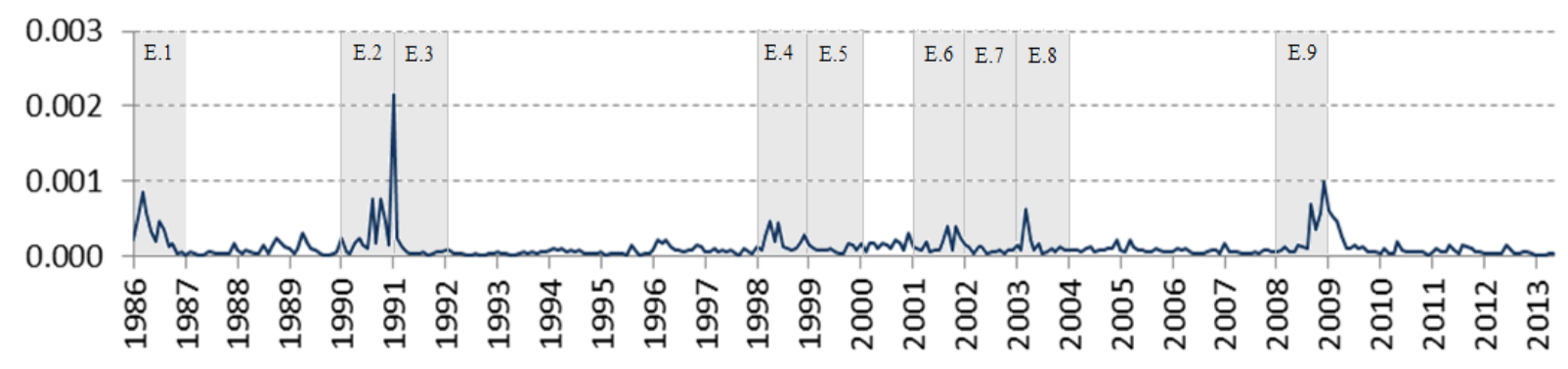




\section{Figure 3}

Cumulative responses of merchandise trade to oil market shocks
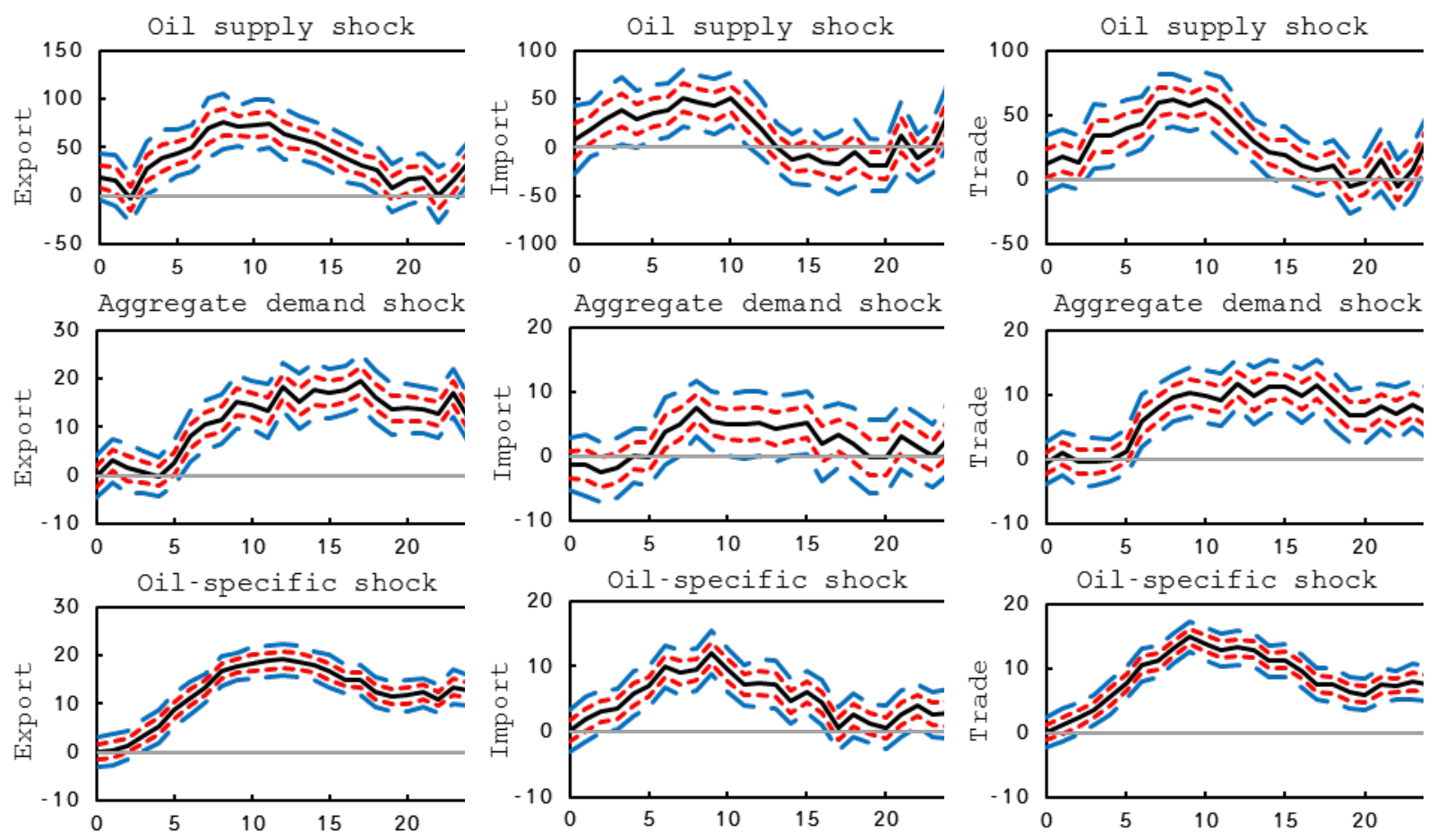

Notes: Figure shows cumulative responses of merchandise trade variables to global oil market structural shocks using Equations 5 and 6. One and two-standard error bands estimated using bootstrap simulation.

\section{Figure 4}

Forecast error variance decomposition of oil market structural shocks
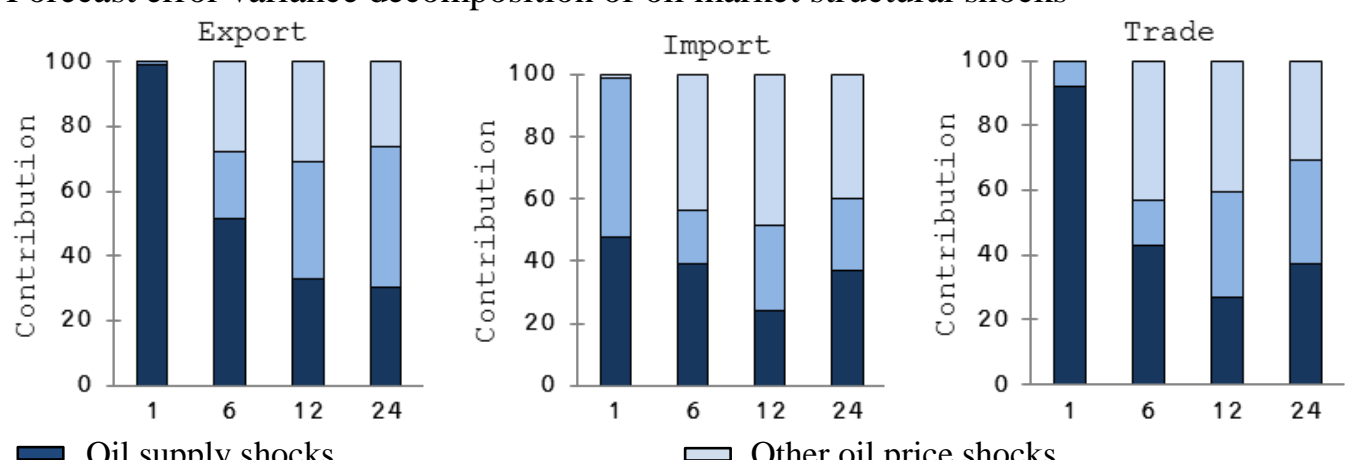

Aggregate demand shocks

$\square$ Other oil price shocks 


\section{Figure 5}

Cumulative responses of merchandise trade to oil price volatility
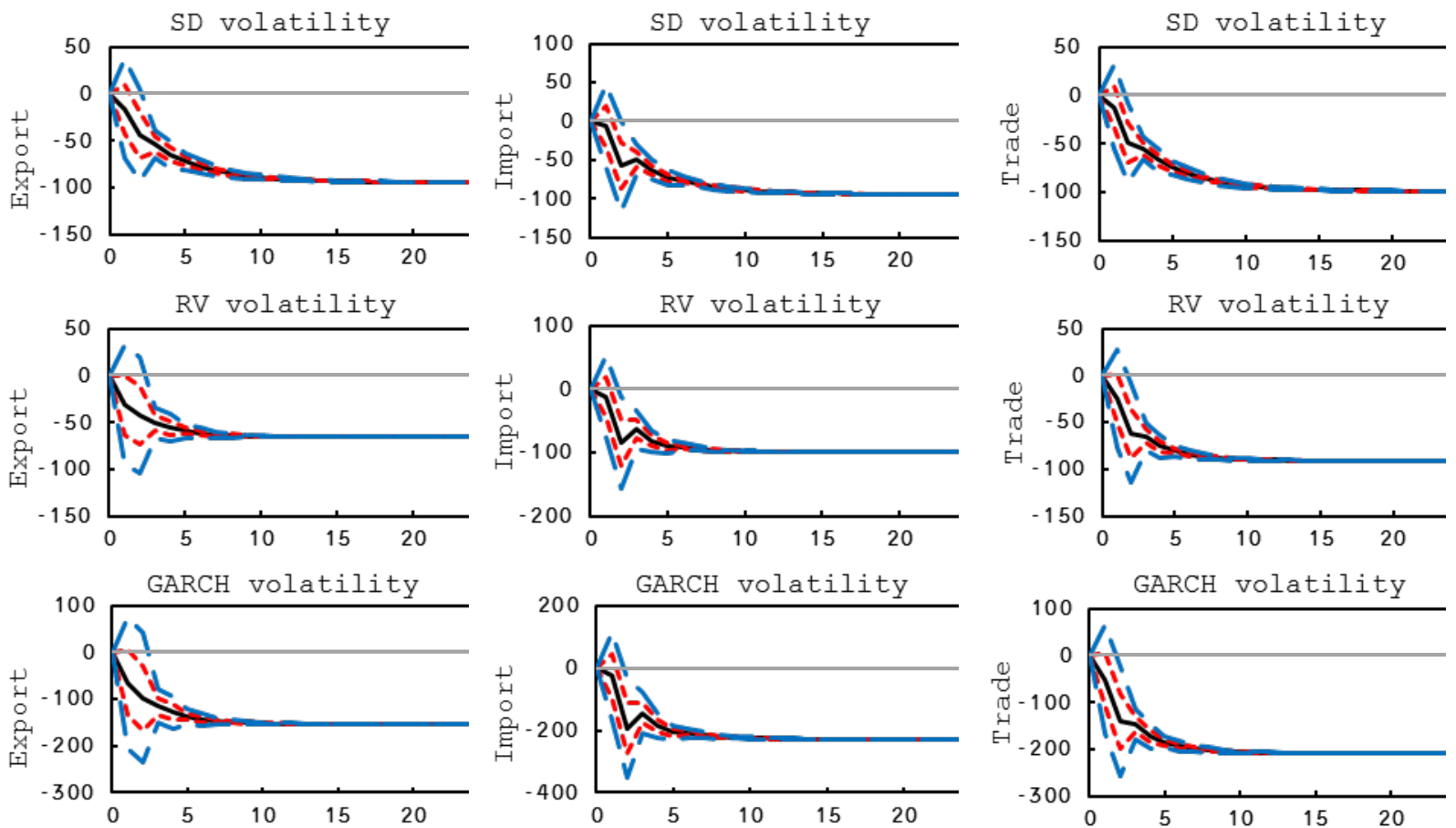

Notes: Figure shows cumulative responses of merchandise trade to global oil price volatility. One and two standard errors displayed in figures. 